\title{
Direct identification of amyloid peptide fragments in human $\alpha$-synuclein based on consecutive hydrophobic amino acids
}

Yongzhu Chen ${ }^{\dagger \dagger}$, Fei Peng ${ }^{\dagger, \S}$, Tao Su ${ }^{\Delta}$, Hao Yang ", Feng Qiu ${ }^{\dagger, \S, *}$

$\dagger$ Laboratory of Anesthesia and Critical Care Medicine, Translational Neuroscience

Center and National Clinical Research Center for Geriatrics, West China Hospital, Sichuan University, Chengdu, 610041, China

¥ Periodical Press of West China Hospital, Sichuan University, Chengdu, 610041, China

$\S$ Department of Anesthesiology, West China Hospital, Sichuan University, Chengdu, 610041, China

$\triangle$ West China-Washington Mitochondria and Metabolism Research Center, West China Hospital, Sichuan University, Chengdu, 610041, China

" Key Lab of Transplant Engineering and Immunology, MOH, West China Hospital, Sichuan University, Chengdu, 610041, China.

\section{Corresponding Author}

*Feng Qiu, E-mail: fengqiu@scu.edu.cn 


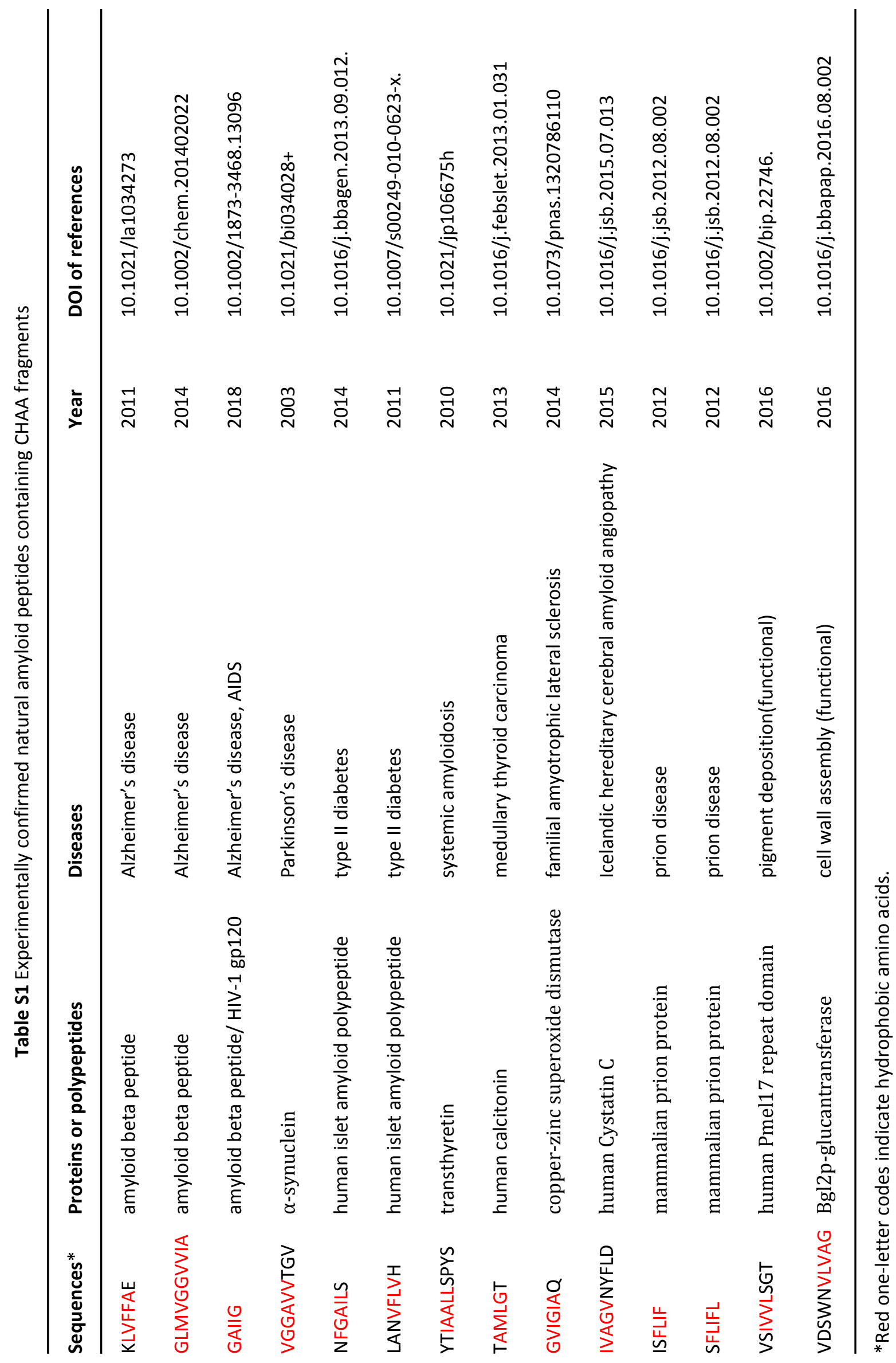




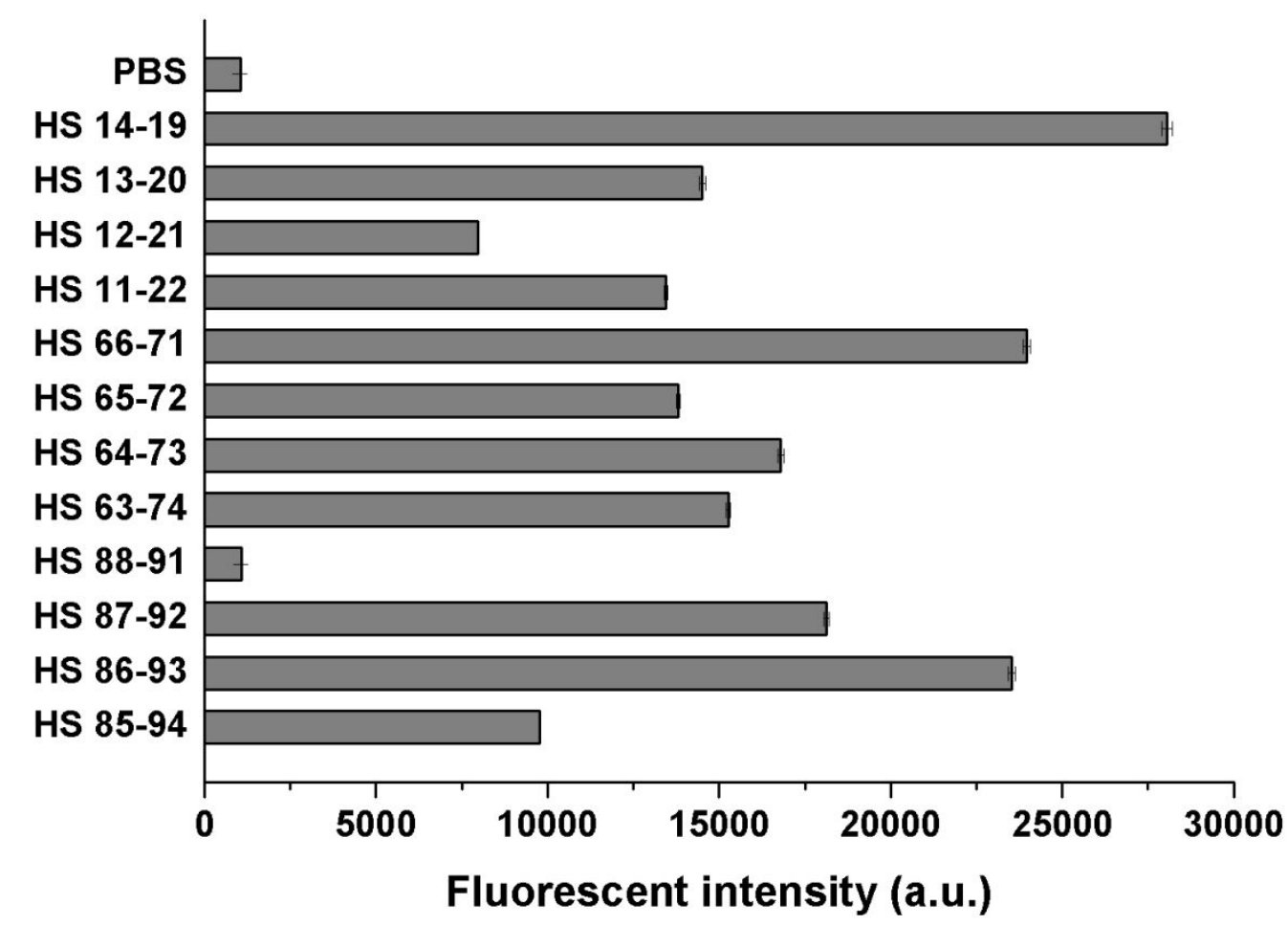

Figure S1 ThT-binding fluorescent intensity at $495 \mathrm{~nm}$ of different CHAA motifs and their extended fragments. 